Marcin DOCHNIAK

Akademia Sztuki Wojennej ${ }^{1}$

Wydzial Wojskowy

Katedra Sit Powietrznych i Obrony Powietrznej

m.dochniak@akademia.mil.pl

ORCID 0000-0002-2953-5776

https://doi.org/10.34739/dsd.2020.02.10

\title{
PERSPEKTYWA GEOPOLITYCZNA A OCENA PRZECIWNIKA POWIETRZNEGO
}

\begin{abstract}
ABSTRAKT: Dokonywana w sposób ciągły na etapie planowania i realizacji działań przez siły powietrzne ocena przeciwnika powietrznego przekłada się na podejmowane decyzje. Autor w artykule rozważa przydatność geopolityki jako perspektywy do jej prowadzenia. Wskazując na wartość informacyjną myśli geopolitycznych wykazuje jej przydatność jako źródła szeregu istotnych danych nie tylko o przestrzeni działań, lecz także o występujących na niej aktorach i ich interesach. Najważniejszymi wnioskami płynącymi z rozważań nad zastosowaniem perspektywy geopolitycznej do prowadzenia oceny przeciwnika powietrznego są oszczędność czasu oraz poprawa świadomości sytuacyjnej jednocześnie na wszystkich szczeblach dowodzenia siłami powietrznymi.
\end{abstract}

SŁOWA KLUCZOWE: geopolityka, siły powietrzne, ocena

\section{GEOPOLITICAL PERSPECTIVE AND THE ASSESSMENT OF THE ADVERSARY AIR FORCES}

\begin{abstract}
Estimation of adversary air force is continuously made during planning process and execution phase and has influence on decisions made. In the article, the author considers the usefulness of geopolitics as a perspective for conducting estimation of adversary air force. Pointing to the informational value of geopolitical thoughts, he shows its usefulness as a source of a number of important data about not only the environment, but also potential political actors and their goals. The most important conclusions from the considerations are that use of geopolitical perspective to estimate adversary air force gives an opportunity to save time and to improve situational awareness at all levels of air force command structure.
\end{abstract}

KEYWORDS: geopolitics, air forces, estimation

${ }^{1}$ War Studies Academy; Poland 


\section{WPROWADZENIE}

Zmienność jest cechą charakteryzującą środowisko bezpieczeństwa międzynarodowego. Wynika to między innymi z faktu nieustannego ścierania się racji występujących na arenie międzynarodowej ośrodków siły² (państw), które często mają odmienne interesy polityczne. W związku z tym znalezienie punktu odniesienia lub perspektywy do oceny możliwości realizacji przez poszczególne państwa założonych celów oraz wskazanie możliwie najbardziej prawdopodobnego i najbardziej niebezpiecznego wariantu, w jakich mogą być te cele osiągane, nastręcza szeregu trudności. Państwo na arenie międzynarodowej możemy rozpatrywać poprzez pryzmat instrumentów władzy (dyplomatyczne, informacyjne, militarne, ekonomiczne) czy też efektów (politycznych, militarnych, ekonomicznych, społecznych, informacyjnych i infrastrukturalnych), będących następstwem wykorzystania tychże instrumentów ${ }^{3}$. Warto jednak zauważyć, że istnieje element charakteryzujący przestrzeń prowadzenia działań, który można uznać za stały, a mogący mieć zastosowanie w ocenie potencjalnego czy też faktycznego adwersarza. Elementem tym jest środowisko geograficzne, które tworzą: skorupa ziemska, część atmosfery, hydrosfera, pokrywa glebowa, szata roślinna i świat zwierzęcy ${ }^{4}$. Eksploracją naukową związków między prowadzoną przez państwa polityką a środowiskiem geograficznym zajmuje się geopolityka.

Obecnie rozwijane podejścia do planowania i prowadzenia działań w ramach operacji, zarówno rosyjskie, jak i amerykańskie, wskazują na zmianę proporcji w zakresie wykorzystania instrumentów władzy na korzyść innych niż militarne. Ponadto podkreślane jest znaczenie doboru wykorzystywanych środków ${ }^{5}$ dla osiągnięcia powodzenia prowadzonych działań. Implikuje to konieczność rozumienia i postrzegania sytuacji w sposób holistyczny przez osoby odpowiedzialne za użycie poszczególnych instrumentów władzy. Zatem również dowódcy wojskowi transponując cele polityczne na cele militarne, a także w toku prowadzenia działań, powinni mieć na uwadze nie tylko osiąganie celów im przypisanych, lecz także określony przez poziom polityczny pożądany stan końcowy. Wymaganiem wpływającym na przebieg realizowanych przedsięwzięć pozostaje niezmiennie dokonanie oceny przeciwnika. Jednym z zasadniczych instrumentów wykorzystywanych przez państwa do prowadzenia polityki, w tym osiągania celów militarnych, są siły powietrzne. Skłania to do podjęcia próby odpowiedzi na pytanie: Jak perspektywa geopolityczna może być wykorzystana na potrzeby

\footnotetext{
${ }^{2}$ Ośrodek siły to ulokowana na określonej przestrzeni zorganizowana struktura polityczno-społeczna, dysponująca władzą centralną, zdolna do oddziaływania na zewnątrz i do egzekwowania władzy w strukturach wewnętrznych - L . Sykulski, Geopolityka a bezpieczeństwo Polski, Warszawa 2018, s. 221.

${ }^{3}$ Vide: D.S. Hartley III, DIME/PMESII Models, [w:] P. Vos Fellman, Y. Bar-Yam, A.A. Minai (eds), Conflict and Complexity Countering Terrorism, Insurgency, Ethnic and Regional Violence, New York 2015, s. 111-135.

${ }^{4}$ Vide: Srodowisko geograficzne, PWN, https://encyklopedia.pwn.pl/haslo/srodowisko-geograficzne;3984316.html (14.05.2019).

${ }^{5}$ Vide B. Герасимов, Ценность науки в предвидении, ВПК, 27 февраля - 5 марта 2013 года, № 8 (476), s. 2; J.M. Reilly, Multidomain Operations A Subtle but Significant Transition in Military Thought, Air and Space Power Journal, Vol. 30, No.1 Spring 2016, s. 61-73.
} 
oceny przeciwnika powietrznego? Odpowiedź na nie wymaga spojrzenia na siły powietrzne z punktu widzenia myśli geopolitycznych ${ }^{6}$ i geopolityki stosowanej ${ }^{7}$ ośrodka siły.

\section{WARTOŚĆ INFORMACYJNA PERSPEKTYWY GEOPOLITYCZNEJ}

Istotność kwestii związanych ze środowiskiem geograficznym dla prowadzenia działań (militarnych i niemilitarnych) oraz osiągania zamierzonych celów nie jest rzeczą nową. Już Sun Tzu pisał: „Ukształtowanie terenu służy armii pomocą. Analiza pozycji nieprzyjaciela, przejęcie kontroli nad zwycięstwem, ocena wąwozów i przełęczy oraz dalszej i bliższej okolicy to Tao wyższego generała. Kto je pozna i zastosuje w walce, z pewnością odniesie zwycięstwo. Kto nie pozna ich albo poznawszy nie zastosuje w walce, na pewno zostanie pokonany" ${ }^{8}$. Perspektywa geopolityczna pozwala spojrzeć na to zagadnienie z innej strony. Uznając ważność środowiska geograficznego oraz znając wpływ, jaki wywiera ono na prowadzenie działań militarnych i niemilitarnych, geopolitycy poszukują zależności pomiędzy umiejscowieniem ośrodka siły w środowisku geograficznym, a polityką przez niego prowadzoną. Korzystają przy tym z podejścia retrospektywnego. Analizując dotychczasowy przebieg wydarzeń, ich przyczyny, skutki i uwarunkowania, w danym rejonie, na danym obszarze, a nawet w ujęciu globalnym, poszukują zachodzących prawidłowości. W oparciu o rezultaty swoich dociekań formułują wnioski dotyczące możliwych przyszłych działań ośrodków siły. Ich uogólnienia wykorzystywane są na poczet opracowania myśli geopolitycznych.

Niezmienność środowiska geograficznego sprawia, że góry utrudniające transport towarów i przemarsz wojsk są wciąż w tym samym miejscu. Przełęcze, rzeki, morza i równiny również nie zmieniają swojego położenia. Kluczowe z punktu widzenia kontroli danego obszaru miejsca pozostają zatem niezmienne. Geopolityka jest nie tylko źródłem informacji dotyczącej szlaków komunikacyjnych, jakie istniały kiedyś i istnieją do dziś, lecz przede wszystkim wpływu, jaki wywarły one na politykę państwa. Należy zaznaczyć, że wspomniana niezmienność nie oznacza całkowitego braku zmian istotności poszczególnych miejsc. Wenecja, ważna z geopolitycznego punktu widzenia w starożytności i wczesnym średniowieczu, utraciła w epoce wielkich odkryć geograficznych i w wyniku budowy Kanału Sueskiego swoje znaczenie dla kontroli przepływu towarów i wojsk pomiędzy Europą, przez Lewant w kierunku Azji. Nadal jednak położona jest na ważnym szlaku lądowym. Podobnie cofanie się lodów Arktyki i starania rosyjskiego ośrodka siły związane z uczynieniem Północnej Drogi Morskiej ważnym szlakiem

\footnotetext{
${ }^{6}$ Myśl geopolityczna to zbiór „poglądów, wniosków i opinii dotyczących środowiska międzynarodowego, odnoszących się do przestrzeni geograficznej i jej roli w kształtowaniu procesów politycznych, a także wyobrażeń dotyczących przestrzeni polityczno-geograficznej i ich roli w kształtowaniu się działalności politycznej”. W myśli geopolitycznej wyróżnić możemy: teorie, doktryny, koncepcje, idee i ideologie - Vide: L. Sykulski, Geopolityka. Skrypt dla początkujacych, Częstochowa 2014, s. 40-44.

7 Geopolityka stosowana - metoda skutecznego wykorzystania wiedzy z zakresu geografii, historii, nauk politycznych, wojskowych i ekonomicznych w celu jak najskuteczniejszej realizacji interesów politycznych danego państwa (ośrodka siły) - L. Sykulski, Geopolityka a..., op. cit., s. 214.

${ }^{8}$ Sun Tzu, Sun Pin, Sztuka wojny, Gliwice 2004, s. 115.
} 
morskim pomiędzy Rimlandem ${ }^{9}$ azjatyckim i europejskim może wywołać pewne zmiany. Jego uruchomienie nie spowoduje jednakże zamknięcia pozostałych szlaków wodnych, może natomiast przyczynić się do zmian hierarchii ich ważności. Kluczowym jest w tym kontekście by rozumieć, iż geopolityka nie determinuje polityki państw, lecz wskazuje i umożliwia zhierarchizować dostępne możliwości wynikające ze środowiska geograficznego, w jakim umiejscowiony jest dany ośrodek siły.

Już pobieżna analiza piśmiennictwa z zakresu geopolityki pozwala przekonać się, że zostało opracowanych wiele myśli geopolitycznych. Część z nich jest nowatorska, a część opiera się na pewnych modyfikacjach myśli geopolitycznych ojców-założycieli geopolityki tj. F. Retzela, R. Kjelléna, F. Naumanna, H.J. Mackindera, A. Mahana, P.V. de la Blache, N.J. Spykmana, K. Haushofera czy C. Schmitta ${ }^{10}$. Faktem również jest, iż od rozpadu Związku Socjalistycznych Republik Radzieckich (ZSRR) geopolityka zyskuje na znaczeniu. Dla podmiotów kształtującego się po rozpadzie układu bipolarnego, policentrycznego świata myśli geopolityczne okazują się skutecznym narzędziem pozwalającym na definiowanie swoich interesów na arenie międzynarodowej. Zarówno Stany Zjednoczone Ameryki (USA), Federacja Rosyjska, jak i liczne państwa Europy korzystają z ich dorobku w czasie analizy sytuacji międzynarodowej. Przejawia się to w podejmowanych przez te państwa działaniach oraz w zapisach ich dokumentów programowych w sferze bezpieczeństwa ${ }^{11}$. Warto w tym miejscu podkreślić fakt wpływu tez głoszonych przez H. Kissingera czy Z. Brzezińskiego na politykę amerykańską oraz ideologii neoeurazjatyzmu A. Dugina na politykę rosyjską. w Polsce natomiast dostrzegalny jest obecnie wpływ koncepcji geopolitycznej Międzymorza, autorstwa E. Romera, a propagowanej w okresie dwudziestolecia międzywojennego między innymi przez J. Piłsudskiego. Przejawy myślenia i podejmowania działań na arenie międzynarodowej przez elity polityczne, przez pryzmat myśli geopolitycznych zauważalne są na co dzień. Przykładami tego są działania w Syrii, rywalizacja na Morzu Południowochińskim czy budowa gazociągu Północny Strumień-2. Wszystkie one wpisują się w ramy geopolityki światowej i można uznać, że są oznaką myślenia przez decydentów kategoriami geopolitycznymi.

Nadal aktualne wydają się pozostawać słowa Clausewitza, że „wojna jest jedynie kontynuacją polityki przy wykorzystaniu innych środków”, ${ }^{2}$, oraz M. Walzera, że „,polityka to kontynuacja wojny innymi środkami" ${ }^{13}$. Siły powietrzne stanowią instrument polityki państwa wykorzystywany niezależnie od stanu stosunków międzynarodowych tj. w czasie pokoju,

\footnotetext{
${ }^{9}$ Nazwa obszaru obejmującego Wielką Brytanię, Północną i Południową Amerykę, Afrykę (na południe od Sahary) Australię, Indonezję i Japonię, wprowadzona do geopolityki przez N.J. Spykmana - Vide: N. J. Spykman, America's strategy in world politics: The United States and the balance of power, Harcourt Brace and Company, New York 1942; Idem, The geography of the peace, New York 1944.

${ }^{10}$ А. Дугин, Основы Геополитики. Геополитическое будущее России., Москва 2000, s. 2.

${ }^{11}$ Vide: Strategia bezpieczeństwa narodowego FR z 31 grudnia 2015 r. (Стратеия национальной безопасности Российской Федераџии от 31 декабря 2015 г.); Strategia Bezpieczeństwa Narodowego USA z grudnia 2017 r. (National Security Strategy of the United States of America December 2017); Strategiczny przeglad obrony i bezpieczeństwa narodowego Francji 2017 (Revue stratégique de défense et de sécurité nationale la France 2017).

${ }^{12}$ C. von Clausewitz, $O$ wojnie, Gliwice 2013, s. 22.

${ }^{13}$ M. Walzer, Spór o wojnę, Warszawa 2006, s. 7.
} 
kryzysu i wojny ${ }^{14}$. W każdym z nich ich zasadnicze zadanie odnosi się do posiadania, walki o posiadanie czy też utrzymania wymaganego stopnia kontroli przestrzeni powietrznej. Nie należy jednak zapominać, że posiadanie takiego czy innego stopnia kontroli przestrzeni powietrznej nie jest celem samym w sobie. Stanowi ono środek umożliwiający użycie posiadanego potencjału w środowisku geograficznym w danym czasie ${ }^{15}$. Dlatego też rozważania nad zastosowaniem perspektywy geopolitycznej na potrzeby oceny przeciwnika powietrznego należy prowadzić z pominięciem rozróżnienia na czas pokoju, kryzysu i wojny ${ }^{16}$.

Zasadnym wydaje się, by w tym miejscu zwrócić uwagę na pewien być może truizm, o którym częstokroć zapominają również oficerowie sił powietrznych - siły powietrzne to nie tylko lotnictwo. Siły powietrzne tworzą wojska lotnicze, wojska radiotechniczne oraz wojska obrony przeciwlotniczej. W ich skład zaliczyć należy również naziemne jednostki radioelektroniczne, realizujące na korzyść sił powietrznych przedsięwzięcia wsparcia radioelektronicznego, obrony radioelektronicznej, a także przeciwdziałania radioelektronicznego. Podkreślenie takiego a nie innego składu sił powietrznych ma na celu zwrócenie uwagi na fakt, że zdecydowana większość sił i środków sił powietrznych, w czasie realizacji zadań, nie znajduje się w powietrzu, lecz na powierzchni Ziemi. Warto również pamiętać o tym, że statek powietrzny posiadający nawet możliwość tankowania w powietrzu, wcześniej czy później będzie musiał wylądować i zostać obsłużony na powierzchni Ziemi. A zatem siły powietrzne, pomimo że posiadają zdolność do wykorzystania trzeciego wymiaru przestrzeni walki, pozostają zależne od elementów napowierzchniowych w trakcie realizacji swoich zadań. Stąd też potrzeba dokonywania oceny środowiska geograficznego prowadzonych działań nie tylko z punktu widzenia statku powietrznego, lecz także z punktu widzenia elementów naziemnych sił powietrznych ${ }^{17}$. Związane jest to również za faktem, że pojawienie się i rozwój lotnictwa nie stanowił czynnika zmieniającego paradygmat geopolityki.

Dokonując oceny przeciwnika powietrznego skupić powinniśmy się przede wszystkim na zidentyfikowaniu jego silnych i słabych stron. Podejście takie umożliwia późniejszą identyfikację środka ciężkości przeciwnika i jego analizę. Upraszczając cały proces oceny przeciwnika powietrznego, wychodząc od przymiotów i ograniczeń sił powietrznych oraz

\footnotetext{
${ }^{14}$ B. Balcerowicz, Sity zbrojne w państwie i stosunkach międzynarodowych, Warszawa 2006, s. 20-29 i 106-107.

${ }^{15}$ Zgodnie $\mathrm{z}$ obecnym podejściem narodowym wyróżniamy trzy stopnie kontroli przestrzeni powietrznej: korzystna sytuacja powietrzna, przewaga w powietrzu, panowanie w powietrzu - Vide: Polaczone operacje powietrzne DD-3.3(B), Bydgoszcz 2014, s. 2-1-2-2.

${ }^{16}$ Warto odnieść się w tym miejscu również do kwestii przestrzeni kosmicznej. Nie jest ona objęta przytoczoną definicją środowiska geograficznego i do niego nie należy. Przestrzeń kosmiczna graniczy ze środowiskiem geograficznym i faktem jest, że siły i środki rozmieszczone w kosmosie mogą kontrybuować w osiąganiu celów w środowisku geograficznym. Niemniej jednak posiadanie rozlokowanych w przestrzeni kosmicznej sił i środków oraz wymaganego do ich wykorzystania stopnia jej kontroli nie będzie celem prowadzonych działan. Podobnie jak posiadanie wymaganego stopnia kontroli przestrzeni powietrznej będzie ono stanowiło jedynie środek umożliwiający wykorzystanie własnego potencjału kosmicznego do osiągania założonych celów. Efekty użycia tegoż potencjału będą zaś widoczne w środowisku geograficznym. $Z$ tego też względu oraz zważywszy na poziom ogólności prowadzonych rozważań wyodrębnianie przestrzeni kosmicznej jako ich czynnika wydaje się niezasadne.

${ }^{17} \mathrm{Z}$ obserwacji autora niniejszej publikacji poczynionych w trakcie udziału w ćwiczeniach z zakresu planowania użycia sił powietrznych na szczeblu komponentu powietrznego, w Polsce, USA i w Niemczech, wynika, że dokonując oceny czynników operacyjnych oficerowie sił powietrznych nagminnie ograniczają się w nich do kwestii związanych tylko z użyciem lotnictwa. Co intrygujące, czynią tak również oficerowie z wojsk radiotechnicznych oraz wojsk przeciwlotniczych.
} 
mając na uwadze czynniki operacyjne (czas, informację, przestrzeń, siły) dokonujemy oceny możliwości, jakimi dysponują siły powietrzne przeciwnika, identyfikujemy czynniki mające wpływ na realizację przez nie zadań, a następnie opracowujemy najbardziej prawdopodobny i najbardziej niebezpieczny wariant ich użycia. Nie zapominamy przy tym o naszym zamiarze i zdefiniowanych celach prowadzenia działań ${ }^{18}$.

Chociaż opisany powyżej sposób postępowania może wydawać się prosty, to jego realizacja już taka łatwa nie jest. Wymaga zbierania i poddawania analizie, a następnie syntezie i wnioskowaniu szeregu danych, z uwzględnieniem nie tylko relacji, lecz także interferencji pomiędzy poszczególnymi identyfikowanymi czynnikami. Stąd też potrzeba poszukiwania perspektywy, która umożliwi sprawny przebieg tego procesu, a także nie spowoduje obniżenia wiarygodności jego rezultatów. Jedną z możliwych wydaje się perspektywa geopolityczna. Za zasadne można uznać, by rozważań nad jej zastosowaniem do oceny przeciwnika powietrznego dokonać w kontekście czynników operacyjnych tj. informacji, czasu, przestrzeni i sił ${ }^{19}$. Z uwagi na fakt, że pozostają one ze sobą w relacjach racjonalnych, ważne jest, by rozpatrzyć je wspólnie, a nie każdy z osobna. Niemniej jednak ze względu na to, iż mowa jest o ocenie przeciwnika powietrznego, która bazuje na informacji, kontekst tego czynnika operacyjnego będzie wiodący.

Mając na uwadze czynniki operacyjne, zwłaszcza informację, należy stwierdzić, że geopolityka może wspierać proces oceny przeciwnika powietrznego dostarczając między innymi danych o wpływie środowiska geograficznego na przepływ informacji. Odnosi się to w szczególności do oceny możliwości i wymagań dotyczących organizacji systemu łączności na obszarze działań. Z uwagi na swój interdyscyplinarny charakter oraz uwzględnianie w analizach geopolitycznych aspektów historycznych i kulturowych może być również przydatna przy doborze środków przekazu, za pomocą których można dotrzeć do społeczności zamieszkującej dany region. Oddziaływanie informacyjne na ludność autochtoniczną może z kolei ułatwić prowadzenie działań przez naziemne elementy sił powietrznych.

Patrząc z punktu widzenia planowania działań powietrznych, geopolityka dostarcza informacji o przestrzeni prowadzenia działań, w tym o potencjalnych ośrodkach siły na teatrze działań i ich interesach geopolitycznych. Pozwala na zidentyfikowanie antagonizmów między nimi, których eksploatacja może przynieść potencjalnie korzyści. Stanowi wartościowe źródło danych historycznych obejmujących kwestie ekonomiczne (handel), społeczne (kultura, religia), dyplomatyczne (polityka i stosunki międzynarodowe) oraz militarne (wojny, konflikty). Będąc wynikiem analizy doświadczeń z konfliktów zbrojnych w danym rejonie dostarcza wniosków z nich płynących, w tym potencjalnych scenariuszy przebiegu działań na danym obszarze. Ze względu na swój holistyczny charakter geopolityka może być pomocna w doborze instrumentów władzy, jakie powinny zostać zastosowane, jak również przy określeniu potencjalnych efektów ich użycia i zadań dla sił powietrznych. To zaś pozwala na poprawę efektywności wykorzystania sił

\footnotetext{
${ }^{18}$ Opisany sposób postepowania odnosi się zarówno do przeciwnika rzeczywistego, jak i potencjalnego. Jego ocena, czy też jej weryfikacja, winna być prowadzona w sposób ciągły w czasie pokoju, kryzysu i wojny.

${ }^{19}$ Doktryna planowania na poziomie strategiczno-operacyjnym D-5, Bydgoszcz 2015, s. 67-68.
} 
powietrznych i bezpośrednio przekłada się na ocenę przeciwnika powietrznego, którą prowadzi się przecież przede wszystkim pod kątem zadania własnego.

Znajomość geopolityki umożliwia spojrzenie na przes trzeń z punktu widzenia nie tylko środowiska geograficznego, lecz także dostarcza informacji dotyczących zidentyfikowanych i eksploatowanych na przestrzeni lat szlaków komunikacyjnych. Ponadto ułatwia wskazanie potencjalnie istotnych obszarów na teatrze działań oraz możliwych ograniczeń dla prowadzania działań na nim. Elementy te są natomiast kluczowe w kontekście estymacji potencjału sił powietrznych potrzebnego do prowadzenia działań, jak i jego dyslokacji w środowisku geograficznym. Perspektywa geopolityczna ułatwia również ocenę możliwości manewrowych i zdolności w zakresie projekcji siły przez siły powietrzne.

Kluczowym w kontekście prowadzenia i planowania działań, w tym również oceny przeciwnika powietrznego, jest czynnik czasu. Zastosowanie perspektywy geopolitycznej do oceny przeciwnika powietrznego pozwala na jego zaoszczędzenie. Znajomość geopolityki niesie ze sobą szeroką wiedzę z zakresu zarówno geografii, jak i polityki. Autorzy myśli geopolitycznych argumentują ich słuszność wskazując prawidłowości wykorzystania środowiska geograficznego. Zatem osoby zaznajomione $\mathrm{z}$ nimi nie powinny mieć trudności ze zidentyfikowaniem jego kluczowych elementów, mogących mieć wpływ na ocenę przeciwnika powietrznego. W sposób dość oczywisty prowadzi to do skrócenia czasu potrzebnego na analizę kluczowych aspektów, zarówno na etapie planowania, jak i prowadzenia działań przez siły powietrzne.

\section{Przyklad Zastosowania}

W celu sklaryfikowania powyższego posłużmy się uproszczonym przykładem opartym na polskim ośrodku siły. W myślach geopolitycznych polski ośrodek siły lokowany jest między innymi w Rimlandzie (N. J. Spykman), w półksiężycu wewnętrznym (H.J. Mackinder), wielkim limotrofie (W. Cymburski) czy kordonie sanitarnym (A. Dugin). Położony jest on na pomoście bałtycko-czarnomorskim. Jest to obszar pomiędzy Morzem Bałtyckim, a Morzem Czarnym, którego granice stanowią od zachodu i południa Odra, Nysa Łużycka, Sudety i Karpaty, zaś od wschodu i północy Dniepr i Dźwina. Polski ośrodek siły leży na styku Nizin Środkowoeuropejskiej i Wschodnioeuropejskiej, które obejmują zasadniczą część jego terytorium. Przebiega przez niego główny lądowy szlak komunikacyjny pomiędzy Europą Zachodnią, a Europą Wschodnią. Patrząc od obszaru rdzeniowego polskiego ośrodka siły w kierunku obszaru rdzeniowego rosyjskiego ośrodka siły szlak ten prowadzi przez Bramę Brzeską, tj. pas szeroki na około $80 \mathrm{~km}$ pomiędzy Narwią a Bugiem. Następnie prowadzi dalej na wschód, będąc od południa ograniczany przez bagniste i trudne do komunikacji obszary wzdłuż Prypeci. Zakończony jest Bramą Smoleńską, tj. szerokim na około $90 \mathrm{~km}$ pasem pomiędzy Dźwiną a Dnieprem, oddzielającym zlewiska Morza Bałtyckiego i Morza Czarnego. Szlak ten był na przestrzeni wieków wykorzystywany 
wielokrotnie w czasie prowadzenia działań wojennych, których uczestnikami były państwa znajdujące się po jego obu stronach ${ }^{20}$.

Przyjmijmy, że potencjalnym przeciwnikiem powietrznym Polski będzie rosyjski ośrodek sił w granicach obecnej Rosji (z wyłączeniem obwodu kaliningradzkiego). Opierając się wyłącznie na powyższych informacjach, zaczerpniętych z myśli geopolitycznych, możemy wyciągnąć szereg wniosków istotnych z punktu widzenia jego oceny. Między innymi to, że teren nie będzie miał zasadniczego wpływu na prowadzenie działań przez lotnictwo, przy założeniu, że nie będzie ono wymagało ciągłego wsparcia ze strony elementów naziemnych (np. naprowadzania, rozpoznania). Działania elementów naziemnych sił powietrznych będą ograniczane przepustowością szlaku i wykorzystaniem go przez innych użytkowników (np. wojska lądowe, transport cywilny). Kluczowymi rejonami, o których kontrolę będzie prowadzona rywalizacja, będą Brama Brzeska i Brama Smoleńska. Bagna wzdłuż Prypeci znacznie ograniczają możliwości manewrowe na obszarze pomiędzy obiema Bramami. Tym samym siły między nie wprowadzone mogą zostać użyte tylko na jednym kierunku. Chęć zapewnienia ciągłej strefy rozpoznania radiolokacyjnego przestrzeni powietrznej nad oboma kluczowymi rejonami, z wykorzystaniem urządzeń naziemnych, będzie wymagała ich rozmieszczenia $\mathrm{w}$ obszarze pomiędzy Bramami. Odległość pomiędzy Bramami, wynosząca około $650 \mathrm{~km}$, będzie wpływała na możliwości realizacji zadań przez lotnictwo bazujące w obszarze rdzeniowym ośrodka rosyjskiego, powodując najprawdopodobniej konieczność zapewnienia możliwości dotankowania w powietrzu.

Należy w tym miejscu zauważyć, że na ocenę przeciwnika powietrznego będzie miała również wpływ ideologia geopolityczna realizowana przez dane państwo, stanowiące potencjalnego przeciwnika powietrznego. Pozostając przy przykładzie rosyjskiego ośrodka siły można wskazać na trzy reprezentowane w nim obecnie ideologie geopolityczne. Są nimi neoeurazjatyzm ${ }^{21}$, atlantyzm ${ }^{22}$ i izolacjonizm ${ }^{23}$. W każdej z nich szlak komunikacyjny wiodący

\footnotetext{
${ }^{20}$ Vide: L. Sykulski, Geopolityka a..., op. cit., s. 197-198.

${ }^{21}$ Neoeurazjatyzm opiera się na paradygmacie binarnym, rywalizacji pomiędzy cywilizacjami morza (talassokracją) i lądu (tellurokracją). Przestrzenią jej prowadzenia jest Rimland, celem zaś kontrola nad nim. Ideologia ta postuluje podział Eurazji na cztery imperia, przypisując rosyjskiemu ośrodkowi siły kluczową rolę. Pozostałymi imperiami są w niej niemiecki ośrodek siły, irański ośrodek siły i japoński ośrodek siły. Czynnikiem spajającym je jest wspólny wróg, którym są atlantyści z USA w roli lidera - Vide: А. Дугин, Основы..., op. cit., s. 106-142; P. Eberhardt, Koncepcje geopolityczne Aleksandra Dugina, „Przegląd Geograficzny” 2010, t. 82, Zeszyt 2, s. 221-240.

${ }^{22} \mathrm{~W}$ myśl ideologii atlantyzmu rosyjski ośrodek siły powinien zacieśniać współpracę z Zachodem, rozumianym nie jako Europa Zachodnia, Unia Europejska czy USA, a jako panujące tam wartości, normy i poziom rozwoju technologicznego. Powinien odrzucić dążenia mocarstwowe i zachowując autonomię w zakresie polityki globalnej dążyć do wzmocnienia relacji opartych na liberalnym podejściu do zapewnienia bezpieczeństwa. Nie chodzi zatem o integrację ze strukturami zachodnimi, ale o budowanie bliskich i wzajemnie korzystnych relacji - Vide: L. Sykulski, Rosyjska geopolityka a wojna informacyjna, Warszawa 2019, 41-44; D. Trenin, The End of EURASIA: Russia on the Border Between Geopolitics and Globalization, Moskow 2001.

${ }^{23}$ Zgodnie $\mathrm{z}$ tą ideologią izolacjonizmu, po odrzuceniu neoeurazjatyzmu i atlantyzmu głównym celem rosyjskiego ośrodka siły powinien być rozwój cywilizacyjny centrum i wschodu kraju, aż po Ocean Spokojny. A zatem winien on skupić się na geopolityce wewnętrznej, a nie zewnętrznej, odrzucając dążenia wielkomocarstwowe. Jest to związane z faktem, że po rozpadzie ZSRR rosyjski ośrodek siły stał się wyspa, którą okala wielki limitrof, rozciągający się od Europy Wschodniej aż po Azję. Stanowi on granicę zarazem chroniącą i energetyzująca obszar rdzeniowy rosyjskiego ośrodka siły, stwarzając warunki do jego niezakłóconego rozwoju - Vide: В. Цымбурский,
} 
przez Bramę Brzeską i Bramę Smoleńską będzie odgrywał ważną rolę, lecz rola ta inaczej będzie się przekładała na zadania dla sił powietrznych, a dokładniej na wysiłek przydzielany na realizację poszczególnych z nich.

Pozostając na dotychczasowym poziomie uproszczenia, w przypadku realizacji założeń atlantyzmu można przypuszczać, że siły powietrzne Rosji prowadziłyby działania w kooperacji z pozostałymi państwami w regionie. Głównym zadaniem jej sił powietrznych byłoby wykonywanie zadań związanych z nadzorem przestrzeni powietrznej ${ }^{24}$. Mało prawdopodobna byłaby rozbudowa potencjału ofensywnego oraz budowa systemów wzbraniania dostępu do teatru działań i ograniczanie możliwości manewru na obszarze operacji (Anti-Access/Area Denial - A2/AD). Elementy sił powietrznych dyslokowane byłyby przede wszystkim w rejonie obszaru rdzeniowego rosyjskiego ośrodka siły. Szlak pomiędzy Bramami traktowany byłby jako obszar bez dominacji któregokolwiek z państw.

Chcąc realizować ideologię izolacjonizmu rosyjski ośrodek siły potrzebowałby silniejszych niż w przypadku atlantyzmu sił powietrznych. Ich głównym zadaniem nadal pozostałby nadzór przestrzeni powietrznej, lecz prawdopodobnym jest rozwijanie również systemów $A 2 / A D$, mających chronić „wyspiarski” charakter ośrodka. Elementy sił powietrznych byłyby rozmieszczane bliżej granic, co pozwoliłoby na zwiększenie ich promienia działania ze stacjonowania w bazach macierzystych, a jednocześnie stwarzało warunki do reagowania na zagrożenia w obszarze wielkiego limitrofu. Należy oczekiwać, że rosyjskie siły powietrzne cechowałby w omawianej sytuacji charakter defensywny, ale również dysponowałyby większymi niż w przypadku realizacji ideologii atlantyzmu możliwościami ofensywnymi. Ponadto, z uwagi na brak kooperacji z sąsiadami w realizacji zadań, siły powietrzne musiałyby być większe niż w poprzednim przypadku. Realizacja ideologii izolacjonizmu wiązałaby się z posiadaniem przez siły powietrzne Rosji zdolności do utrzymania co najmniej korzystnej sytuacji powietrznej w przestrzeni na wschód od Bramy Brzeskiej.

W przypadku realizacji przez rosyjski ośrodek siły ideologii neoeurazjatyzmu należałoby oczekiwać, że będzie on dysponował siłami powietrznymi zdolnymi do projekcji siły nie tylko w obronie własnego obszaru rdzeniowego, lecz także na wysuniętych rubieżach. Prawdopodobnie rozwijałby i dyslokował on swoje systemy A2/AD w taki sposób, by sięgały one w głąb obszaru kontrolowanego przez niemiecki ośrodek siły i obejmowały cały obszar kordonu sanitarnego. Pełnienie roli mocarstwa wiodącego wymuszałoby posiadanie już nie tyle potencjału defensywnego, co raczej ofensywnego. Realizując omawianą ideologię rosyjski ośrodek siły dążyłby najprawdopodobniej do posiadania możliwości projekcji siły i co najmniej korzystnej sytuacji powietrznej również nad całym obszarem rdzeniowym polskiego ośrodka siły. Tym samym nie tylko w rejonach Bramy Brzeskiej i Bramy Smoleńskiej przestrzeń

\footnotetext{
Земля за великии лимитрофом: от «России-Евразии» к «России в Евразии», http://alternatio.org/articles/articles/ item/574-земля-за-великим-лимитрофом-от-россии-евразии-к-россии-в-евразии $\quad(17.05 .2019) ; \quad$ J. Potulski, Wspótczesne kierunki rosyjskiej myśli geopolitycznej, Gdańsk 2010, s. 205-255.

${ }^{24}$ Rozumianym jako wykorzystanie systemów obserwacji i kontroli przestrzeni powietrznej, środków dowodzenia i kontroli oraz odpowiednich środków obrony powietrznej, włączając przechwytujące statki powietrzne w celu zachowania integralności przestrzeni powietrznej - Vide AAP-6 Edition 2018, Brussels 2018, s. 85.
} 
powietrzna byłaby „kontrolowana” przez rosyjskie siły powietrzne, lecz także „kontrola” ta sięgałaby w głąb obszaru rdzeniowego Polski, czyniąc szlak komunikacyjny w całości nadzorowanym przez stronę rosyjską.

Warto w tym miejscu jeszcze raz podkreślić, że powyższa egzemplifikacja i wyciągnięte z niej wnioski, składające się na ocenę potencjalnego przeciwnika powietrznego, są tylko przykładowymi. Wyartykułowano je w celu pokazania, że perspektywa geopolityczna dostarcza szeregu przydatnych informacji. Nie stanowią więc one pełnej i wyczerpującej oceny zarówno środowiska, jak i potencjału powietrznego potencjalnego przeciwnika. Niemniej jednak cechują się wartością ilustratywną w odniesieniu do omawianego zagadnienia.

\section{PodsumoWANIE}

Reasumując, perspektywa geopolityczna wydaje się przydatna na potrzeby oceny przeciwnika powietrznego. Jej zastosowanie pozwala na wyciągnięcie szeregu wniosków i uzyskanie przynajmniej wstępnej świadomości sytuacyjnej w relatywnie krótkim czasie. Warto w tym miejscu podkreślić, że to właśnie czas, a dokładnie zdolność do szybszego niż przeciwnik przeprowadzenia procesu planowania i przejścia do działań jest kluczowa, gdy chce się osiągnąć ich powodzenie. Jak pokazuje opisany powyżej uproszczony przykład zastosowania perspektywy geopolitycznej, dostarcza ona informacji nie tylko o wpływie środowiska geograficznego na działania potencjalnego przeciwnika powietrznego, lecz także umożliwia ocenę jego zamiarów zdefiniowanych w realizowanej przez dany ośrodek siły ideologii geopolitycznej, a tym samym podjęcie próby predykcji działań, jakie prawdopodobnie będą realizowały jego siły powietrzne. Jej zastosowanie pozwala ponadto wykluczyć pewne scenariusze działania jako mało prawdopodobne, a jednocześnie uprawdopodobnić inne. To wszystko przekłada się nie tylko na poprawę zrozumienia zamiarów adwersarza, lecz także na dobór i dyslokację sił i środków sił powietrznych mających im przeciwdziałać. Wartym podkreślenia jest fakt, że perspektywa geopolityczna prowadzi do poprawy zrozumienia sytuacji jednocześnie na wszystkich szczeblach dowodzenia, co -jak wskazano - jest obecnie uznawane za kluczowe. Nie należy jednak zapominać, że jej zastosowanie wymaga posiadania dość szerokiej wiedzy z zakresu myśli geopolitycznych, a także historii, geografii, polityki czy stosunków międzynarodowych. Uzasadnioną wydaje się zatem potrzeba zdobywania jej przez oficerów sił powietrznych w czasie realizacji procesu kształcenia.

W rozważaniach skupiono się przede wszystkim na wskazaniu zalet, jakie może nieść ze sobą wykorzystanie perspektywy geopolitycznej do oceny przeciwnika powietrznego. Nie znaczy to, że należy ją uznać za podejście zapewniające kompleksową i pełną realizację tego procesu. Zasadnym wydaje się, by dokonując oceny przeciwnika powietrznego, korzystać z możliwie szerokiej gamy dostępnych metod i podejść, zwiększając tym samym prawdopodobieństwo osiągnięcia sukcesu. Prawdziwą zdaje się teza, że perspektywę geopolityczną można uznać za komplementarną w stosunku do innych podejść do oceny przeciwnika powietrznego. Istnieje szereg przesłanek, że 
jej zastosowanie może przynieść korzyść w trakcie planowania i prowadzenia działań, przekładając się nie tylko na oszczędność czasu, sił i środków, lecz także zmniejszenie ryzyka związanego $\mathrm{z}$ niepewnością.

\section{BIBLIOGRAFIA}

AAP-6 Edition 2018. 2018. Brussel: NATO Standardization Office.

Balcerowicz Bolesław. 2006. Siły zbrojne w państwie i stosunkach międzynarodowych. Warszawa: Wydawnictwo Naukowe SCHOLAR.

Clausewitz von Carl. 2013. O wojnie. Gliwice: Helion.

Doktryna planowania na poziomie strategiczno-operacyjnym D-5, 2015. Bydgoszcz: MON CDiSzSZ.

Дугин Александр. 2000. Основы Геополитики. Геополитическое будущее России. Москва: АРКТОГЕЯ-центр [Dugin Aleksandr. 2000. Osnovy Geopolitiki. Geopoliticheskoe budushchee Rossii. Moskva: ARKTOGEJA-tsentr].

Eberhardt Piotr. 2010. Koncepcje geopolityczne Aleksandra Dugina. Przegląd Geograficzny 82 (2). 221-240.

Герасимов Валерий. 2013. Ценность науки в предвидении. ВПК 8 (476). 2-3 [Gerasimov

Valeriij. 2013. Tsennost' nauki v predvidenii. VPK 8(476). 2-3].

Hartley III Dean. 2015. DIME/PMESII Models. Conflict and Complexity Countering

Terrorism, Insurgency, Ethnic and Regional Violence. New York: Springer.

Połączone operacje powietrzne DD-3.3(B). 2014. Bydgoszcz: MON CDiSzSZ.

Potulski Jakub. 2010. Współczesne kierunki rosyjskiej myśli geopolitycznej. Gdańsk:

Wydawnictwo Uniwersytetu Gdańskiego.

Reilly Jeffrey. 2016. Multidomain Operations A Subtle but Significant Transition in Military

Thought. Air and Space Power Journal No.1 Vol. 30. 61-73.

Spykman Nicholas John. 1942. America's strategy in world politics: The United States and the balance of power. New York: Harcourt Brace and Company.

Spykman Nicholas John. 1944. The geography of the peace. New York: Harcourt Brace and Company.

Strategia bezpieczeństwa narodowego FR z 31 grudnia 2015 r. (Стратеия национальной безопасности Российской Федерации от 31 декабря 2015 г.).

Strategia Bezpieczeństwa Narodowego USA z grudnia 2017 r. (National Security Strategy of the United States of America December 2017).

Strategiczny przegląd obrony i bezpieczeństwa narodowego Francji 2017 (Revue stratégique de défense et de sécurité nationale la France 2017).

Sun Tzu, Sun Pin. 2004. Sztuka wojny. Gliwice: Helion.

Sykulski Leszek. 2018. Geopolityka a bezpieczeństwo Polski. Warszawa: Zona Zero.

Sykulski Leszek. 2014. Geopolityka, Skrypt dla początkujących. Częstochowa: Wydawnictwo Naukowe Grategia.

Sykulski Leszek. 2019. Rosyjska geopolityka a wojna informacyjna. Warszawa: PWN.

Trenin Dmitri. 2001. The End of EURASIA: Russia on the Border Between Geopolitics and

Globalization. Moscow: Carnegie Endowment for International Peace.

Walzer Michael. 2006. Spór o wojnę. Warszawa: Muza. 


\section{ŹRÓDLA INTERNETOWE}

PWN. https://encyklopedia.pwn.pl.

Цымбурский Вадим. 2019. Земля за великим лимитрофом: от «России-Евразии» к «России в Евразии» В http://alternatio.org/articles/articles/item/574-земля-завеликим-лимитрофом-от-россии-евразии-к-россии-в-евразии [Tsimburskij Vadim. 2019. Zamlya za velikim limitrofom: ot „Rossi-Evrazii” k „Rossii v Evrazii” V http://alternatio.org/articles/articles/item/574-земля-за-великим-лимитрофом-отроссии-евразии-к-россии-в-евразии] 